
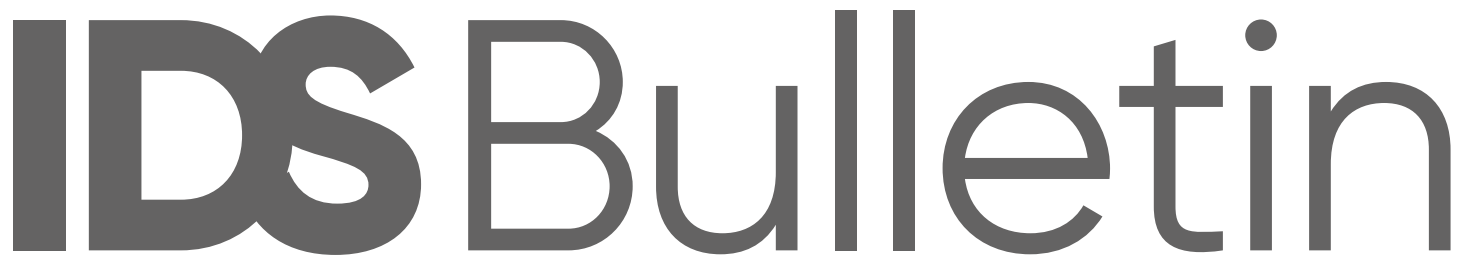

Transforming Development Knowledge

Volume 52 | Number 2 | November 2021

\title{
CHINA AND INTERNATIONAL DEVELOPMENT: KNOWLEDGE, GOVERNANCE, AND PRACTICE
}

\author{
Editors Xiaoyun Li, Jing Gu and Chuanhong Zhang
}

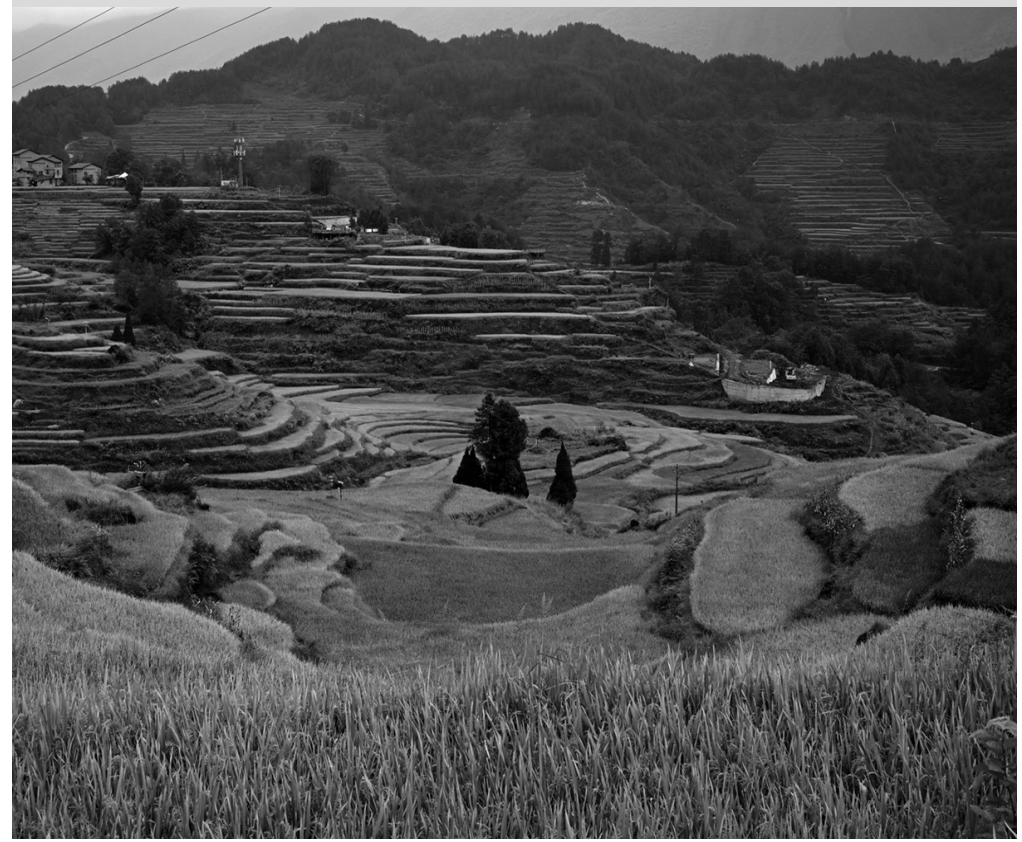


Notes on Contributors

Whose Knowledge? Whose Influence? Changing Dynamics of China's

Development Cooperation Policy and Practice

Jing Gu, Xiaoyun Li and Chuanhong Zhang

Mutual Learning in Development Cooperation: China and the West

Jiantuo Yu and Evan Due

The New Asian Development Finance Karin Costa Vazquez and Yu Zheng

Exploring China's Impacts on Development Thinking and Policies

Jiajun Xu and Richard Carey

China's NGO Partnerships in a New Era of Development Cooperation

Anthea Mulakala, Robin Bush and Hongbo Ji

Ownership and Effectiveness of China's Aid Projects in Africa

Chuanhong Zhang, Xiaoyun Li and Dawit Alemu

Selective Learning: China, the CGIAR, and Global Agricultural Science in Flux Xiuli Xu, Lídia Cabral and Yingdan Cao

Chinese Foundations and the Challenge of 'Going International'

Lindan Tan and Huib Huyse

Triangular Cooperation: Different Approaches, Same Modality

Sebastian Prantz and Xiaomin Zhang

Glossary 


\title{
The New Asian Development Finance*
}

\author{
Karin Costa Vazquez ${ }^{1}$ and Yu Zheng ${ }^{2}$
}

\begin{abstract}
The recent challenges posed for multilateralism and the emergence of a sustainable development regime have pushed countries to engage in more flexible, issue-based development finance initiatives and institutions. These changes have profoundly impacted how China conceives and delivers its development finance. How is China's development finance being shaped by other countries' experiences? How has China been shaping development finance globally? This article argues that China's development finance has been increasingly market-oriented, concerned about financial and environmental sustainability, and delivered through hybrid bilateral-multilateral channels, particularly since the launch of the Belt and Road Initiative. Shaped by the changes that China experienced at both international and domestic levels, these new features signal the rise of a 'new Asian development finance' that is refocusing the global debate on the importance of combining aid, trade, and investment under financially and environmentally sustainable frameworks, and channelling development finance through multilateral channels to catalyse structural transformation.
\end{abstract}

Keywords development finance, the Asian model, multilateralism, sustainable development.

\section{Introduction}

Over the past two decades, the global economic landscape has been shifting with the rise of emerging economies and developing countries, on the one side, and the relative decline of developed countries' share in world output, on the other. These changing dynamics in the global economy have also had a profound effect on international development as emerging economies become even more important sources of development finance on both bilateral and multilateral fronts. More recently, the challenges posed for multilateralism have pushed countries worldwide to prefer more flexible, fluid, and issue-based development finance initiatives and institutions over models of global economic governance that prioritise negotiations within standing, formal, 
treaty-based bodies with universal membership (Patrick 2015, 2019; Ikenberry 2018; Vazquez 2021).

The emergence of international commitments to sustainable development, signalled by the 2030 Agenda for Sustainable Development (the 2030 Agenda), the Paris Agreement on climate change, and the Addis Ababa Action Agenda for financing sustainable development, has further pushed countries to align their own development goals more closely with notions of sustainability. The creation of the New Development Bank (NDB) and the Asian Infrastructure Investment Bank (AllB) in 2015 reflects these changes, with both institutions born out of two innovative platforms for multilateralism: South-South cooperation and a mandate anchored on sustainability (Vazquez, Roychoudhury and Borges 2017; Vazquez and Chin 2019; Vazquez 2021).

With four decades of remarkable economic performance, China has also become more confident in sharing its development experiences with other emerging and developing countries. This can be seen in the expansion of the transformation of development finance. Three new features have emerged as China's development finance has transformed itself over the last decade under the Belt and Road Initiative (BRI) umbrella. First, it has adopted a more market-oriented strategy through an explicit combination of aid, trade, and investments. Second, it is more concerned about financial and environmental sustainability in response to the rising concern of debt distress and environmental impact. Third, it has become hybrid in nature as it is increasingly being delivered through earmarked United Nations (UN) programmes and the new multilateral development banks. These new features, we argue, have been prompted by institutional changes in China's aid coordination system and slowly shaped by China's economic rebalancing and the changing global landscape, particularly after the 2008 global financial crisis.

Other Asian economies also share similar features in conceiving and delivering their development finance, signalling the rise of a new development finance model that has China and, more broadly, Asia at its epicentre. This new Asian development finance has been refocusing the global debate on the importance of state-led (blended) finance to support infrastructure and sustainable development, both as a driver to endogenous structural transformation and economic growth as well as a tool to advance countries' economic, policy, and strategic goals. More than a convergence between traditional donors and emerging economies, the new Asian development finance could signal the emergence of alternative narratives in international cooperation for development.

\section{The new features of China's development finance}

Over the last decade, China has extensively increased its development finance, becoming one of the leading capital 


\begin{tabular}{lll}
\hline Development finance & Features & Evidence \\
\hline Types & Increasing market orientation & $\begin{array}{l}\text { Declining share of aid in development } \\
\text { finance }\end{array}$ \\
\hline Criteria & $\begin{array}{l}\text { Emphasis on financial and environmental } \\
\text { sustainability }\end{array}$ & $\begin{array}{l}\text { Debt sustainability framework, green } \\
\text { investment and financing regulations, } \\
\text { new multilateral development banks' } \\
\text { commitment to sustainability, more } \\
\text { renewable energy projects }\end{array}$ \\
\hline Channels & Hybrid multilateral-bilateral channels & $\begin{array}{l}\text { More earmarked multilateral funds, and } \\
\text { new multilateral development banks, credit } \\
\text { programmes, and special funds }\end{array}$ \\
\end{tabular}

providers in developing countries. Three new features of China's development finance have emerged during the time, as summarised in Table 1.

\subsection{Increasing market orientation}

The first feature of China's new development finance is its increasing market orientation, as evidenced by the more explicit combination of official development assistance (ODA)-like aid and commercial forms of economic engagement. Today, China's development finance is less about the narrow construct of 'aid' or ODA, as defined by the Development Assistance Committee (DAC) of the Organisation for Economic Co-operation and Development (OECD) in terms of grants, interest-free loans, and concessional loans, and more about export buyers' credits, non-concessional loans, strategic lines of credit, and other resource flows such as remittances (Lakatos et al. 2016; Mawdsley 2021; Mulakala 2021; SCIO 2021).

Even though Chinese development finance has long had a commercial nature, the percentage of aid has been declining over the past decade while the commercial part of the finance continues to increase, especially after the launch of the BRI. From 2003 to 2019, Chinese development finance to Africa increased from US\$20bn to US\$340bn, but China's global foreign aid only increased from US\$0.6bn to US\$3.1bn. ${ }^{3}$ Foreign aid expenditure even dropped sharply after 2015 before it rebounded to a new high in 2019. This trend can also be observed in the 2015 and 2018 editions of the Forum on China-Africa Cooperation (FOCAC) when the country pledged a total of US\$120bn in financing for Africa, of which only a small proportion came in the form of grants, interest-free loans, or concessional loans. ${ }^{4}$ Indeed, after the creation of two policy banks - the Export-Import Bank of China (China Exim Bank) and the China Development Bank (CDB) - the proportion of concessional loans (issued by the Exim Bank) 
and non-concessional loans (mainly issued by the CDB) rose, while the proportion of interest-free loans dropped sharply (Morgan and Zheng 2019; Chen 2020).

Since the beginning of the twenty-first century, commercial financial institutions have also become important sources of development finance. The number of Chinese creditors in the overseas market expanded from two public lenders (Exim Bank and the CDB) in 2000 to over 30 lenders, including commercial banks and other private creditors in 2019 (Acker and Brautigam 2021). The increase in the number of private creditors in China's development finance signals a new trend whereby publicprivate partnerships are being used to supplement state-led aid programmes as they help alleviate political and financial risks associated with China's aid programmes on the one side, and expand sources of development finance, on the other.

\subsection{Emphasis on financial and environmental sustainability}

China's new development finance has also emphasised financial and environmental sustainability. Over the last decade, China has become the leading official creditor to low-income developing countries, many of which are former highly indebted poor countries and where Chinese capital is particularly important for the financing of large-scale energy and mining projects (Horn, Reinhart and Trebesch 2019). Given the growing concern regarding high debt burdens, China has begun to look more closely into the financial sustainability of its overseas development finance. In 2018, the Ministry of Finance (MOF) released a debt sustainability framework for the BRI low-income countries similar to that of the World Bank and the International Monetary Fund (MOF 2019). Under this framework, Chinese lenders are encouraged to direct development finance to countries that have not previously asked for debt relief while countries with weak records of debt management are likely to receive less capital (Gallagher and Ray 2020; Acker and Brautigam 2021).

Regarding environmental sustainability, since 2012, China's financial regulators have issued a number of regulations in pursuit of green investment and financing. In 2021 alone, China launched the world's largest carbon market, released guidelines to align Chinese international cooperation and foreign investment with green development principles, and published a roadmap towards the decarbonisation of its economy by 2060. China has become the second largest green bond issuer in the world, accounting for a quarter of newly issued global green bonds in 2018 (CDB and UNDP 2019). The major development finance platforms and institutions like the two new multilateral development banks have included notions of environmental sustainability in their mandate (Vazquez and Chin 2019; Vazquez 2021). This growing concern with environmental sustainability can also be seen in the high profile of renewable energy in China's development finance, which has reached 57 per cent of total overseas investments in 2020 (Nedopil 2021). 


\subsection{Delivery through hybrid bilateral-multilateral channels}

China's new development finance is also characterised by the use of both bilateral and multilateral channels, also labelled as 'new multilateralism'. This new multilateralism has two dimensions. The first is the growing use of earmarked contributions to the UN Development System (UNDS). In the past, China was reluctant to move to multilateral lending due to a lack of understanding of how it works and how traditional multilateral channels implied lesser control of how resources are spent, and how outcomes are defined and achieved.

While China's foreign aid remains largely bilateral, the country has also been promoting efforts to support and participate in aid programmes initiated by international organisations such as the UN. Over the last decade, China's overall contribution to the UNDS has quadrupled, with Chinese funding growing at an annual average rate of 33.8 per cent between 2013 and 2017 alone. China's shares of core funding and assessed contribution in its total UNDS funding grew more than that of traditional donors, while the share of non-core funding in China's total contribution jumped from 23 per cent in 2008 to 50 per cent in 2017 (Mao 2020).

In the second dimension of the new multilateralism, China has also made use of its foreign reserves to create new development finance institutions, credit programmes, and special funds with both a portfolio diversification and development finance objectives. This is the case of the China-LAC Cooperation Fund (CLAC), the China-LAC Industrial Cooperation Investment Fund (CLAI), the Fund for Cooperation and Development between China and Portuguese-Speaking Countries, and the Silk Road Fund. One could also add the China Investment Corporation $(\mathrm{ClC})$ and many regional-oriented initiatives as vehicles for investment based on Chinese sovereign reserves. These initiatives culminated in the creation of the AllB and the NDB, headquartered in China but with a global reach and membership.

\section{Causes of the transformation of China's development finance} China's development finance was shaped by the changes that the country experienced at both international and domestic levels, particularly the consolidation of its aid governance structure.

\subsection{Consolidation of aid governance structure}

Traditionally, China's aid governance structure involved more than 20 central line ministries, commissions, and agencies as well as their provincial counterparts (Zhou and Xiong 2017). The decision-making power of China's aid lies with the central government, under the leadership of the Chinese Communist Party (CCP). Three central government agencies - the Ministry of Commerce (MOFCOM), the Ministry of Foreign Affairs (MFA), and MOF - are authorised by the State Council to implement aid projects; ensure that the aid agenda is aligned with broader foreign policy goals; and oversee China's financial contributions 
to multilateral development organisations (Vazquez, Mao and Yao 2016).

In addition to the three major players, the National Development and Reform Commission (NDRC), the Ministry of Science and Technology (MOST), the Ministry of Agriculture (MOA), the Ministry of Education (MOE), the National Health and Family Planning Commission (NHFPC), and other line ministries also take part in China's foreign aid according to their sectorial expertise and by the request of MOFCOM or their counterpart agencies in the partner country. MOFCOM also works closely with the China Exim Bank on concessional loan policies and their implementation. The Chinese embassies abroad coordinate and manage foreign aid projects in the field.

It has long been debated how to make better use of China's growing foreign aid budget and justify its benefits to the domestic public. Over the past decade, mid- and long-term foreign aid plans, country strategies, and evaluations have been developed though they remain unpublicised (ibid.). While Western perceptions often assume deliberate secrecy (Brautigam 2009), Chinese scholars have attributed this to system complexity and fragmentation (Hu and Huang 2012; Huang and Hu 2020). Within a highly decentralised aid architecture, the diverging interests of the bureaucratic and corporate actors can be seen. These actors either regard foreign aid as an instrument for exercising diplomatic influence on the international stage and deepening cooperation with selected countries or as a way of assisting domestic businesses to expand exports and investments (Morgan 2019).

This has called for enhanced efforts to speak with a unified voice and facilitate concerted action in formulating policies and identifying projects (Zheng 2016; Vazquez, Mao and Yao 2016). To strengthen coordination, MOFCOM, MFA, and MOF led 24 central ministries, commissions, and units to establish China's foreign aid interagency liaison mechanism in 2008. In 2011, this liaison mechanism was upgraded into an interagency coordination mechanism (Zhou and Xiong 2017) and in 2018, the China International Development Cooperation Agency (CIDCA) was created to provide central coordination and to better integrate China's foreign aid governance. Since 2013, the BRI has served as the primary platform for institutionalising China's development finance. The establishment of CIDCA has placed the BRI at the core of Chinese aid, helping to articulate China's foreign and economic policy priorities down to the projects supported by the country.

Despite the lingering coordination challenges, this transformation has favoured the development of a strategy that articulates the three new features of China's development finance down to project level. CIDCA has unveiled the new directions of China's development finance in the 2021 White Paper 
China's International Development Cooperation in a New Era (SCIO 2021). This White Paper distinguishes from the 2011 and 2014 versions in three ways. First, the scope and objective of China's foreign aid are no longer limited to traditional bilateral 'aid' or ODA, but a broader discussion about China's SouthSouth development, trade, and investment with both bilateral and multilateral actors. Second, China's foreign aid is, for the first time, partially framed in a non-Chinese framework with the 2030 Agenda presenting an important vision guiding China's contribution to partner countries. Third, the categorisation of what constitutes foreign aid has evolved by including the South-South Cooperation Assistance Fund (SSCAF) as an emerging financing modality in addition to grants, interest-free loans, and concessional loans.

\subsection{An evolving international setting}

At the international level, the transforming global political and economic landscape, especially after the 2008 financial crisis and the decline in aid supplied by traditional donors, laid the conditions for China and other emerging economies to play an even more substantial role in development finance (Manning 2006; Walz and Ramachandran 2011; Hernandez 2017; Gu and Carey 2019; Acker and Brautigam 2021). In the case of China, this includes the use of foreign aid, trade, and investment not only to respond to the growing demand from other emerging and developing economies, but also to create a more favourable international environment for China's own development (Fuchs and Rudyak 2019).

China's rapidly expanding development finance has led to concerns on its supposedly adverse economic and environmental impact in the developing world (Acker and Brautigam 2021). For some authors, China's foreign aid sets agendas (Jakóbowski 2018) and imposes conditionalities (Hirst 2008), making it difficult for countries to pay their debts. For other authors, China's foreign aid fails to comply with local and international environmental standards, keeps local business out of the market, and relies excessively on Chinese workers, thus not creating enough local jobs (Dussel and Armony 2015; Gallagher 2016).

The adoption of the 2030 Agenda, the Paris Agreement, and the Addis Ababa Action Agenda has created additional pressure on China, not only to avoid, mitigate, and compensate any adverse impacts of its foreign aid, but also to align its development finance and institutions with the Sustainable Development Goals (SDGs) and other internationally agreed commitments on climate and development. At the domestic level, China's economic rebalancing and commitment to carbon neutrality by 2060 has started a transition towards a new growth pattern in which domestic consumption, services and high technology, and sustainability are to rise relative to investments and exports, manufacturing, and resource-intensive production. 
The greater public scrutiny and the international commitments on climate and development, coupled with China's economic rebalancing and growing awareness of the risks associated with its foreign aid, have motivated the country to emphasise the financial and environmental sustainability of its development finance. This can be seen in the reduction of CDB and Exim Bank loans from US\$75bn in 2016 to US\$4bn in 2019, signalling a possible rebalancing of China's overseas development finance over concerns around borrowing countries' indebtedness and loan sustainability (Gallagher and Ray 2020; Acker and Brautigam 2021).

The increasing hybrid bilateral-multilateral nature of China's development finance is intended to minimise these credibility, reputational, and operational risks on the one side, while increasing cost efficiency, directing the country's capacity to changing domestic priorities, and seeking greater influence globally, on the other. The growing use of earmarked multilateral funds, for instance, reduces concerns over how resources are spent, and how outcomes are defined and achieved. This thinking is similar in the case of the new multilateral development banks as China figures among their top shareholders - an evolution from the role China and other emerging and developing countries have historically played as borrowers from traditional multilateral development banks (MDBs).

\section{Beyond China: Asian development finance}

China's new development finance has developed alongside the rise of Asia and other emerging countries, as one of the many shifts and disruptors that shape twenty-first-century multilateralism (Kharas and Rogerson 2017; Ikenberry 2018). Over the last two decades, Asia has become the pivot of a structural shift in the centre of the world's economic gravity (Ikenberry 2018; Mulakala 2021). China and India are at the heart of this transformation, accounting for at least one quarter of global output and a significant proportion of the world's middle class. The two countries have also had sustained growth rates and are projected to be the first and second largest economies in the world by 2050 .

The rise of China, Asia, and other emerging countries, as part of the so-called 'global South', has created new and diversified forms of development finance, including the very understanding of foreign aid beyond the OECD-DAC traditional definition of ODA, and the establishment of new international institutions such as the NDB and the AllB (Bhattacharya and Llanos 2017; Fejerskov, Lundsgaarde and Cold-Ravnkilde 2017; Gray and Gills 2018). While these shifts have contributed to an increasingly fragmented landscape of institutions, norms, and standards (Chaturvedi et al. 2021), they have also allowed development models and experiences, other than those of traditional donors, to shape these very institutions, norms, and standards. For example, NDB and AllB focus on infrastructure lending as a 
leverage to economic growth, in contrast to that of traditional MDBs, which have marginalised infrastructure investment to prioritise institutional reforms in borrowing countries (Vazquez, Roychoudhury and Borges 2017).

\subsection{Asian versus Western approaches}

These emerging approaches to development finance are based on domestic development experiences that are substantially different from those in the West. Similarly to China, other Asian countries have emphasised infrastructure, industrialisation, and foreign direct investment as essential drivers of growth with the potential to trickle down into poverty reduction (Stallings and Kim 2017; Gabor and Brooks 2017; Mawdsley 2021). These countries would also have contributed to the emphasis on state-private capital hybrid formations and state-supported development financing (Mawdsley 2015, 2018). This is noticeably different from the Western model, which emphasises immediate poverty alleviation and conditionality to promote democracy, human rights, and 'good' governance in the poorest countries, especially in sub-Saharan Africa.

Asian development finance also tends to come as a package, with a mixture of aid, loans, export credit, and investment (Zheng 2020; Mulakala 2021) to secure natural resources or expand the overseas market for their domestic firms. This occurs alongside the promotion of the economic development of their poorer neighbours through exports and integration into regional production networks (Stallings and Kim 2017). China's official financing, for example, is less concessional than World Bank financing in comparable settings, in addition to systematically offering higher interest rates, shorter maturity lengths, and less generous grace periods (Morris, Parks and Gardner 2020). This would demonstrate the novelty of the commercial nature of Chinese development finance as part of a package of aid and commercial loans vis-à-vis Western models.

The combination of aid, trade, and investment has, in fact, historical precedents in many parts of the world, but lost momentum as newly independent countries realised its costs (Kaplinsky and Morris 2009). More recently, traditional donors have been attempting to reform the ODA system thus: 'increasing alignment of aid with partner countries' priorities, systems and procedures and helping to strengthen their capacities' (OECD 2008: 3), and to use aid to leverage private investment to help promote economic growth (UN 2002). The Paris Declaration on Aid Effectiveness and the Monterrey Consensus on Financing for Development set two different, if not opposing goals for foreign aid: aid effectiveness is important for development, but aid is only part of the solution to development. Ideally, donors can delink aid and commercially oriented capital or trade flows and connect aid with investment. In reality, this dual goal creates a dilemma for the donor community as untying aid requires donors to focus on 
the public interests of the recipient countries whereas leveraging private investment requires attention to the business prospects of aid programmes.

In the post-Covid-19 era, the sizeable financial and political risk underpinning China's global infrastructure boom, particularly in the BRI economies, leaves China's development finance open to the possibilities of huge default losses. It is therefore in China's interest to eventually pay more attention to the domestic issues of partner countries, which may lead to a more flexible application of the 'no-strings-attached' principle. This could be done, for instance, through the joint design of projects to better understand the local reality and to manage any political and economic risks that could harm project viability and long-term sustainability. In the meantime, traditional donors have revised their definition of ODA to add a new international standard Total Official Support for Sustainable Development (TOSSD) - to monitor a broader range of funding, including private resources mobilised through official means, that help countries reach the SDGs. This convergence between the traditional donors and emerging economies on aid conditionality may lead them towards an alternative model that is more inclusive and development oriented.

There is also a global trend towards hybrid forms of bilateralmultilateral development finance. While multilateral development organisations remain the major source of development finance, there is a growing tendency of donors to earmark funds and use ad hoc initiatives to exert greater bilateral influence on international organisations, raising a debate that the system is evolving towards 'à la carte' multilateralism (Vazquez 2021; OECD 2020). This is evident in the substantial increase in non-core funding in the UN system, designated by donors for specific purposes in accordance with their bilateral interests.

Though this hybrid is mainly shaped by traditional donors, such as the US and the UK, who remain the major shareholders and funders of the multilateral development system, it is convenient to China and other Asian and emerging economies as they step up contribution to the multilateral system. According to the OECD (2020), growing contributions from the BRICS (Brazil, Russia, India, China, and South Africa) to the UN system, coupled with their establishment of new multilateral organisations of which they are main shareholders, attest to their rise in influence. Their share of total multilateral contributions to the UN system, while still relatively low at around 4 per cent in 2018, has increased steadily over the past decade.

\subsection{New versus past Asian approaches}

While Asian countries share features of development finance that are noticeably different from Western donors, there are also marked differences between how Asian development finance is 
conceived and practised today and its earlier versions. China and India have, for instance, added 'twenty-first century pivots' (Mulakala 2021: 522) to the East Asian post-war development finance. This has been done by:

- Emphasising investment in big-ticket connectivity schemes such as the BRI and the Asia-Africa Growth Corridor (AAGC) to stimulate growth and reduce poverty. This is an evolution of the East Asian post-war model as it integrates individual infrastructure projects under a broader development framework that combines Asian growth-led models with Western notions of poverty alleviation.

- Increasing multilateral cooperation through the new development banks - in which China and India figure among the top shareholders. This could mean a new economic and political geography of international development cooperation substantially different from that of previous Asian approaches and even the Bretton Woods system (Carey and Li 2016). This new geography could also point to new narratives based on Asian development experiences and the global transformations that will have Asia at its epicentre.

There is also diversity among the current Asian approaches and between Asian and non-Western, non-Asian countries. For example, despite sharing the commercial and multilateral features of East Asian development finance, India has not yet placed the same emphasis on environmental sustainability. Likewise, the commercial and multilateral features of the Asian development finance are generally not shared by non-Western countries outside Asia, especially in Latin America and the Caribbean. The new development banks have been combining aid, trade, and investment under the same institutional mandate while emphasising environmental sustainability, and could become the locus for convergence among these different approaches in the future.

\section{Conclusion}

In the past decade, a new development finance model has been on the rise. This new model was shaped by the transforming global political and economic landscape as well as China's evolving aid governance structure and long-term development goals. Drawing from development experiences in China and other Asian countries, this new development finance model is refocusing the global debate on the importance of combining aid, trade, and investment under financially and environmentally sustainable frameworks, and channelling development finance through multilateral arrangements to catalyse structural transformation.

This new Asian development finance adds 'twenty-first century pivots' (Mulakala 2021: 522) to the East Asian post-war development finance by refocusing infrastructure investment from 
individual projects towards big-ticket connectivity schemes that stimulate growth and reduce poverty. It also elevates China and India to top shareholders in new multilateral development finance institutions and relies on partnerships with the private sector to complement state capacity. Despite being markedly different from Western experiences by emphasising principles such as equality, horizontality, non-conditionality, and mutual benefit, this new Asian development finance increasingly converges with traditional donors on the use of earmarked multilateral funding, the conditionality of development cooperation to ensure economic and environmental sustainability, and the lack of coherent strategies for integrating aid, trade, and investment.

The Covid-19 pandemic has triggered a surge in demand for development financing in all developing countries, particularly low-income countries. It has also pointed to the need to think towards new models for post-pandemic recovery, beyond emergency relief. In this new context, the new Asian development finance could signal new narratives to address countries' short-, medium-, and long-term development needs. Future research could look at how Western notions of development sustainability have emphasised countries' financial ability to repay debts and the use of safeguards to avoid, mitigate, or compensate any negative impacts of investments. These notions seem to oppose the more development-oriented notion of sustainability, as understood by China and other Asian and emerging economies: that privileges the catalytic role investments can play in generating additional positive impact.

\section{Notes}

* This IDS Bulletin was produced as part of the UK Anchor Institution for the China International Development Research Network, funded by the Foreign, Commonwealth $\&$ Development Office (FCDO). The opinions expressed are those of the authors and do not necessarily reflect the views or policies of IDS or the UK government.

1 Karin Costa Vazquez, Scholar, Fudan University, China and Associate Professor and Assistant Dean, O.P. Jindal Global University, India.

2 Corresponding author: Yu Zheng, Professor, School of International Relations and Public Affairs, Fudan University, China. Email: yzheng@fudan.edu.cn.

3 Estimated based on the data from the China-Africa Research Initiative and Boston University Global Development Policy Center (2021). Chinese development finance flows include aid, loans, foreign direct investment, and trade to Africa. See www.sais-cari.org.

4 In 2015, China pledged US\$5bn in grants and interest-free loans; in 2018, the total pledged foreign aid, when concessional loans were included, increased to US\$15bn. See MOFCOM (2015, 2018). 


\section{References}

Acker, K. and Brautigam, D. (2021) 'Twenty Years of Data on China's African Lending', China-Africa Research Initiative Briefing Paper 4, Washington DC: Johns Hopkins University School of Advanced International Studies

Bhattacharya, D. and Llanos, A.O. (2017) Southern Perspectives on the Post-2015 International Development Agenda, London: Routledge

Brautigam, D. (2009) The Dragon's Gift: The Real Story of China in Africa, Oxford and New York NY: Oxford University Press

Carey, R. and Li, X. (2016) The BRICS in International Development: The New Landscape, IDS Evidence Report 189, Brighton: Institute of Development Studies (accessed 5 August 2021)

CDB and UNDP (2019) Harmonizing Investment and Financing Standards towards Sustainable Development along the Belt and Road: Economic Development along the Belt and Road (2019), China Development Bank and United Nations Development Programme (accessed 6 August 2021)

Chaturvedi, S. et al. (2021) The Palgrave Handbook of Development Cooperation for Achieving the 2030 Agenda, London: Palgrave Macmillan

Chen, M. (2020) 'Beyond Donation: China's Policy Banks and the Reshaping of Development Finance', Studies in Comparative International Development 55.4: 436-59

China-Africa Research Initiative and Boston University Global Development Policy Center (2021) Chinese Loans to Africa Database, Version 2.0 (accessed 31 August 2021)

Dussel P.E. and Armony, A.C. (2015) Beyond Raw Materials: Who Are the Actors in the Latin America and Caribbean-China Relationship?, Buenos Aires: Friedrich-Ebert-Stiftung, Red Académica de América Latina y el Caribe sobre China, Center of Latin American Studies, University of Pittsburgh, and Fundación Foro Nueva Sociedad

Fejerskov, A.M.; Lundsgaarde, E. and Cold-Ravnkilde, S. (2017) 'Recasting the "New Actors in Development" Research Agenda', European Journal of Development Research 29.5: 1070-85

Fuchs, A. and Rudyak, M. (2019) 'The Motives of China's Foreign Aid', in Z. Ka (ed.), Handbook on the International Political Economy of China, London: Edward Elgar Publishing

Gabor, D. and Brooks, S. (2017) 'The Digital Revolution in Financial Inclusion: International Development in the Fintech Era', New Political Economy 22.4: 423-36

Gallagher, K.P. (2016) The China Triangle: Latin America's China Boom and the Fate of the Washington Consensus, New York NY: Oxford University Press

Gallagher, K.P. and Ray, R. (2020) 'China Takes the Lead in Development Finance', Project Syndicate, 9 December (accessed 22 April 2021)

Gray, K. and Gills, B.K. (eds) (2018) Rising Powers and South-South Cooperation, London: Routledge 
Gu, J. and Carey, R. (2019) 'China's Development Finance and African Infrastructure Development', in A. Oqubay and J.Y. Lin (eds), China-Africa and an Economic Transformation, Oxford: Oxford University Press

Hernandez, D. (2017) 'Are "New" Donors Challenging World Bank Conditionality?', World Development 96 (August): 529-49

Hirst, M. (2008) 'A South-South Perspective', in R. Roett and G. Paz (eds), China's Expansion in the Western Hemisphere: Implications for Latin America and the United States, Washington DC: Brookings Institution Press

Horn, S.; Reinhart, C.M. and Trebesch, C. (2019) China's Overseas Lending, NBER Working Paper 26050, Cambridge MA: National Bureau of Economic Research (accessed 28 June 2021)

$\mathrm{Hu}$, J. and Huang, M. (2012) 'Current Situation and Reform of China's Foreign Aid Administration [Zhongguo duiwai yuanzhu guanli tixi de xianzhuang yu gaige]', International Economic Cooperation [Guoji jingji hezuo] 10: 55-58

Huang, M. and Hu, J. (2020) 'Foreign Aid Study: Chinese Schools and Chinese Points', The Pacific Review 33.3-4: 520-49

Ikenberry, G.J. (2018) 'Why the Liberal World Order Will Survive,' Ethics and International Affairs 32.1: 17-29

Jakóbowski, J. (2018) 'Chinese-Led Regional Multilateralism in Central and Eastern Europe, Africa and Latin America: $16+1$, FOCAC, and CCF', Journal of Contemporary China 27.113: 659-73

Kaplinsky, R. and Morris, M. (2009) 'Chinese FDI in Sub-Saharan Africa: Engaging with Large Dragons', European Journal of Development Research 21.4: 551-69

Kharas, H. and Rogerson, A. (2017) Global Development Trends and Challenges: Horizon 2025 Revisited, London: Overseas Development Institute (accessed 7 May 2021)

Lakatos, C.; Maliszewska, M.; Osorio-Rodarte, I. and Go, D. (2016) China's Slowdown and Rebalancing: Potential Growth and Poverty Impacts on Sub-Saharan Africa, Policy Research Working Paper 7666, Washington DC: World Bank

Manning, R. (2006) 'Will "Emerging Donors" Change the Face of International Co-Operation?', Development Policy Review 24.4: 371-85

Mao, R. (2020) China's Growing Engagement with the UNDS as an Emerging Nation: Changing Rationales, Funding Preferences and Future Trends, DIE Discussion Paper 2/2020, Bonn: Deutsches Institut für Entwicklungspolitik

Mawdsley, E. (2021) 'Development Finance and the 2030 Goals', in S. Chaturvedi et al. (eds), The Palgrave Handbook of Development Cooperation for Achieving the 2030 Agenda, London: Palgrave Macmillan

Mawdsley, E. (2018) ' "From Billions to Trillions": Financing the SDGs in a World "Beyond Aid"', Dialogues in Human Geography 8.2: 191-95

Mawdsley, E. (2015) 'DFID, the Private Sector, and the Re-Centring of an Economic Growth Agenda in International Development', Global Society 29.3: 339-58 
MOF (2019) Debt Sustainability Framework for Participating Countries of the Belt and Road Initiative, Ministry of Finance, People's Republic of China (accessed 30 June 2021)

MOFCOM (2018) 'Elaboration on the Eight Major Initiatives of the FOCAC Beijing Summit', Ministry of Commerce, 19 September (accessed 4 May 2021)

MOFCOM (2015) 'The Interpretations of the Johannesburg Summit of the FOCAC and the Sixth Ministerial Conference on the 10 Major China-Africa Cooperation Plans in Economic and Trade Domains', Ministry of Commerce, 16 December (accessed 4 May 2021)

Morgan, P. (2019) 'Chinese Development Finance in Africa: Pragmatism, Opportunism and Legacy', PhD dissertation, Fudan University

Morgan, P. and Zheng, Y. (2019) 'Old Bottle New Wine? The Evolution of China's Aid in Africa 1956-2014', Third World Quarterly 40.7: 1283-1308

Morris, S.; Parks, B. and Gardner, A. (2020) Chinese and World Bank Lending Terms: A Systematic Comparison Across 157 Countries and 15 Years, CGD Policy Paper 170, Washington DC: Center for Global Development (accessed 27 June 2021)

Mulakala, A. (2021) 'The "Asian Century": The Transformational Potential of Asian-Led Development Cooperation', in S. Chaturvedi et al. (eds), The Palgrave Handbook of Development Cooperation for Achieving the 2030 Agenda, London: Palgrave Macmillan

Nedopil, C. (2021) China's Investments in the Belt and Road Initiative (BRI) in 2020: A Year of Covid-19, Beijing: Green BRI Center, International Institute of Green Finance (accessed 3 May 2021)

OECD (2020) Multilateral Development Finance 2020, Paris: OECD Publishing (accessed 6 August 2021)

OECD (2008) The Paris Declaration on Aid Effectiveness and the Accra Agenda for Action, Paris: OECD Publishing (accessed 3 May 2021)

Patrick, S. (2019) The Sovereignty Wars: Reconciling America with the World, Washington DC: Brookings Institution Press

Patrick, S. (2015) Multilateralism à la Carte: The New World of Global Governance, Valdai Paper 22, Moscow: Valdai Discussion Club (accessed 18 August 2020)

$\mathrm{SClO}$ (2021) China's International Development Cooperation in the New Era, White Paper, Beijing: State Council Information Office (accessed 2 May 2021)

Stallings, B. and Kim, E.M. (2017) Promoting Development: The Political Economy of East Asian Foreign Aid, London: Palgrave Macmillan

UN (2002) 'Monterrey Consensus on Financing for Development', International Conference on Financing for Development, Monterrey, Mexico, 18-22 March

Vazquez, K.C. (2021) 'Brazil and BRICS Multilateralism à la Carte: From Bilateralism to Community Interest', Global Policy 12.4: 534-38 (accessed 31 August 2021) 
Vazquez, K.C. and Chin, G.T. (2019) 'The AllB and Sustainable Infrastructure: A Hybrid Layered Approach', Global Policy 11.4: 593-603

Vazquez, K.C.; Mao, X. and Yao, S. (2016) Mix and Match? How Countries Deliver Development Cooperation and Lessons for China, Beijing: UNDP and Chinese Academy of International Trade and Economic Cooperation (accessed 26 April 2021)

Vazquez, K.C.; Roychoudhury, S. and Borges, C. (2017) Building Infrastructure for 21st Century Sustainable Development: Lessons and Opportunities for the BRICS-Led New Development Bank, New Delhi: O.P. Jindal Global University (accessed 12 March 2021)

Walz, J. and Ramachandran, V. (2011) Brave New World: A Literature Review of Emerging Donors and the Changing Nature of Foreign Assistance, CGD Working Paper 273, Washington DC: Center for Global Development

Zheng, Y. (2020) 'The Emergence of New Development Assistance: Conceptual and Operational Frameworks', in Y. Jing, A. Mendez and Y. Zheng (eds), New Development Assistance: Emerging Economies and the New Landscape of Development Assistance, London: Palgrave Macmillan

Zheng, Y. (2016) 'China's Development Assistance to Africa: A Viable Solution to International Development', paper presented at the Conference on Development, Trade and Investment, Stockholm School of Economics, Stockholm, Sweden, 26-27 August

Zhou, H. and Xiong, H. (eds) (2017) China's Foreign Aid: 60 Years in Retrospect, Singapore: Springer Singapore 